\title{
Trichilemmoma of the Scalp: An Unusual Presentation
}

\section{Triquilemoma do Couro Cabeludo: Uma Apresentação Pouco Comum}

Rui Pedro Santos ${ }^{1}$, Olga Ferreira ${ }^{1}$, Margarida Teixeira ${ }^{2}$, Celeste Brito ${ }^{1}$

Corresponding Author/Autor Correspondente:

Rui Pedro Santos [drruisantos@hotmail.com]

Rua Santa Bárbara n 52, 4435-595 Baguim do Monte, Gondomar, Portugal

KEYWORDS: Scalp; Skin Neoplasms

PALAVRAS-CHAVE: Couro Cabeludo; Neoplasias da Pele

Trichilemmoma is a benign tumor with origin in the outer root sheath cells of the pilosebaceous follicles. ${ }^{1}$ The relationship between the human papilloma virus and this neoplasm remain controversial.,

Although there are no pathognomonic clinical aspects, it usually presents as an asymptomatic, slow growing, facial papule or nodule. It usually has a dome-like appearance, skin colored or erythematous and a smooth or warty surface. ${ }^{2}$

Trichilemmomas are usually solitary lesions but if multiple tumors (at least three) are found on the face, the hypothesis of Cowden syndrome should be considered. This syndrome shows multiple extracutaneous neoplasms (breast, kidney, intestine) and depends on germline mutations of the tumor suppressor gene PTEN. ${ }^{2}$
The authors report a 79-year-old Caucasian female with prior history of hypertension and dementia with an exophytic, yellowish lesion of the scalp with more than two years of evolution. The dermatological examination revealed an indurated nodular lesion with a hyperkeratotic surface of $1.5 \mathrm{~cm}$ in diameter (Fig. 1). It resembled a cutaneous horn in the inter-parietal region of the scalp.

An excisional biopsy was performed and the histopathological exam revealed a crateriform, well delimitated, trabecular lesion with both endo and exophytic growth. The epithelium had a trabecular growth pattern with abrupt transition in amorphous corneous masses (Fig. 2). The squamous epithelium was hyperplastic with a peripheral layer of palissade cuboid cells and several layers of large squamous cells with pale abundant cytoplasm 


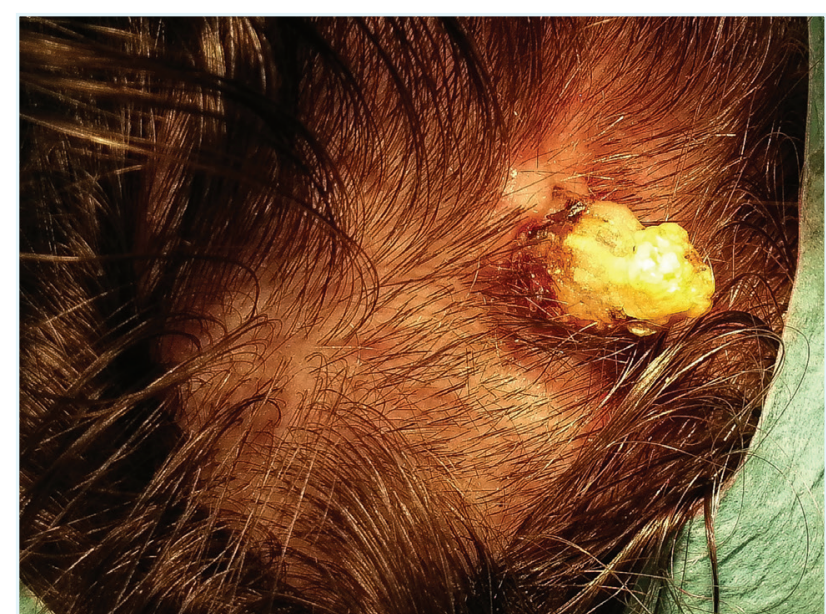

FIGURA 1. An indurated nodular lesion with a hyperkeratotic surface, resembling a cutaneous horn in the inter-parietal region of the scalp.

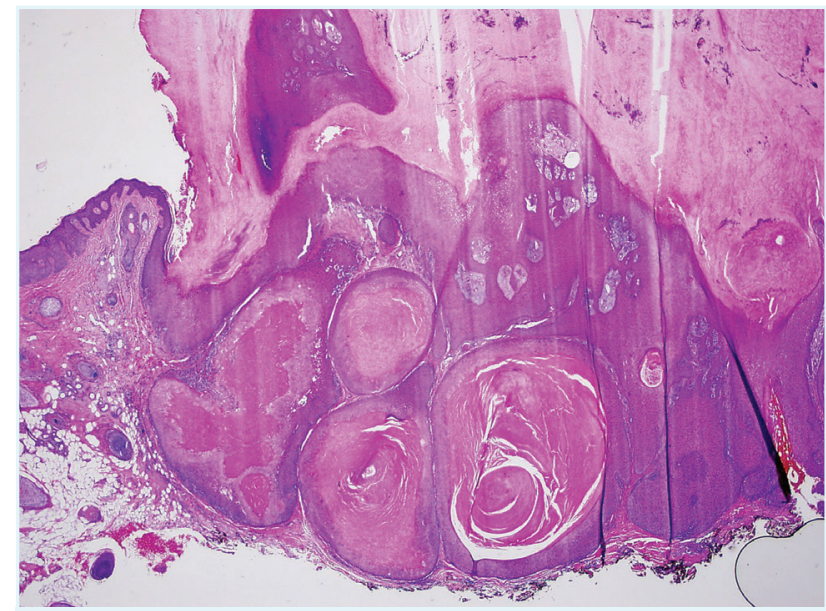

FIGURA 2. H\&E, 20x - Note the crateriform, well delimitated trabecular lesion with both endo and exophytic growth.

that suffered abrupt keratinization without formation of the granular cell layer causing eosinophilic orthokeratotic keratin, the so-called trichilemmic keratinization (Fig.s 3 and 4). The excision was complete and up to date (two-year follow-up), without relapsing.

Trichilemmoma is a benign adnexal tumor and no treatment is necessary. However, an excisional biopsy is mandatory for diagnosis of a neoplasm with no clinical pathognomonic aspects that needs to be differentiated of other adnexal tumors (benign or malignant), basal or squamous cell carcinoma and viral warts. ${ }^{4}$

CONFLICTS OF INTEREST: The authors declare that they have no conflicts of interest.

FINANCIAL SUPPORT: This work has not received any contribution, grant or scholarship.

CONFIDENTIALITY OF DATA: The authors declare that they have followed the protocols of their work center on the publication of data from patients.

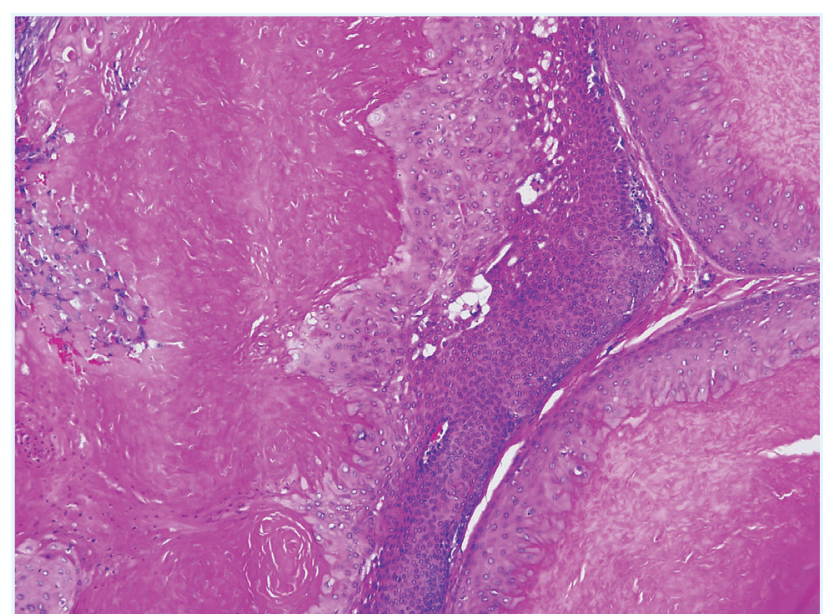

FIGURA 3. H\&E, 100x - Peripheral palisading adjacent to the thickened hyaline eosinophilic basement membrane.

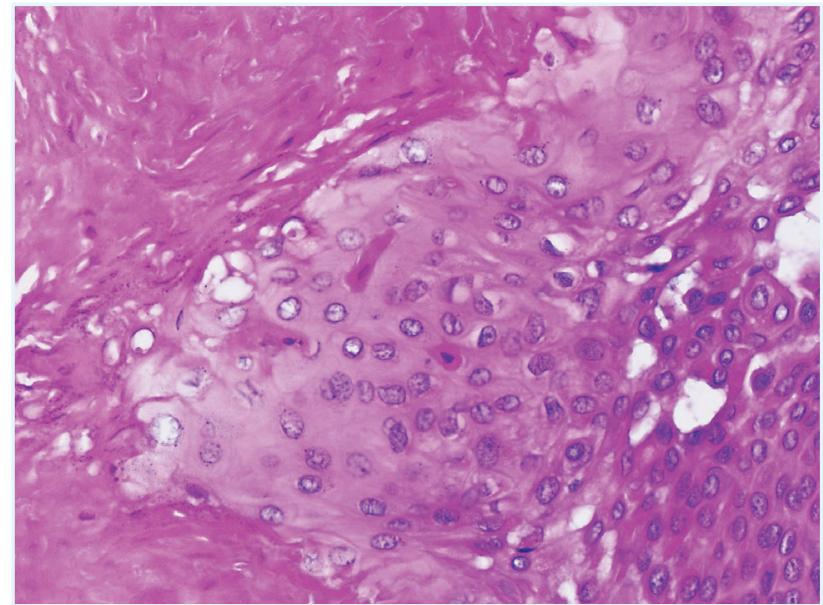

FIGURA 4. H\&E, 400x - Detail of the clear cells and abrupt keratinization.

PROTECTION OF HUMAN AND ANIMAL SUBJECTS: The authors declare that the procedures followed were in accordance with the regulations of the relevant clinical research ethics committee and with those of the Code of Ethics of the World Medical Association (Declaration of Helsinki).

CONFLITOS DE INTERESSE: Os autores declaram não ter qualquer conflito de interesse na realização do presente trabalho.

FONTES DE FINANCIAMENTO: Não houve qualquer fonte de financiamento na realização do presente trabalho.

CONFIDENCIALIDADE DOS DADOS: Os autores declaram ter seguido os protocolos da sua instituição acerca da publicação dos dados de doentes.

PROTEÇÃO DE PESSOAS E ANIMAIS: Os autores declaram que os procedimentos seguidos na elaboração do presente trabalho estão em conformidade com as 
normas das comissões de investigação clínica e de ética, bem como da declaração de Helsínquia e da Associação Médica Mundial.

\section{REFERENCES}

1. Tsai JH, Huang WC, Jhuang JY, Jeng YM, Cheng ML, Chiu HY, et al. Frequent activating HRAS mutations in trichilemmoma. British J Dermatol. 2014;171:1073-7.

2. Tellechea O, Cardoso JC, Reis JP, Ramos L, Gameiro AR, Coutinho I, et al. Benign follicular tumors. An Brasil Dermatol. 2015;90:780-96; quiz 97-8.

3. Kambiz KH, Kaveh D, Maede D, Hossein A, Nessa A, Ziba R, et al. Human Papillomavirus deoxyribonucleic acid may not be detected in non-genital benign papillomatous skin lesions by polymerase chain reaction. Indian J Dermatol. 2014;59:334-8.

4. Sano DT, Yang JJ, Tebcherani AJ, Bazzo LA. A rare clinical presentation of Desmoplastic Trichilemmoma mimicking Invasive Carcinoma. An Brasil Dermatol. 2014;89:796-8. 